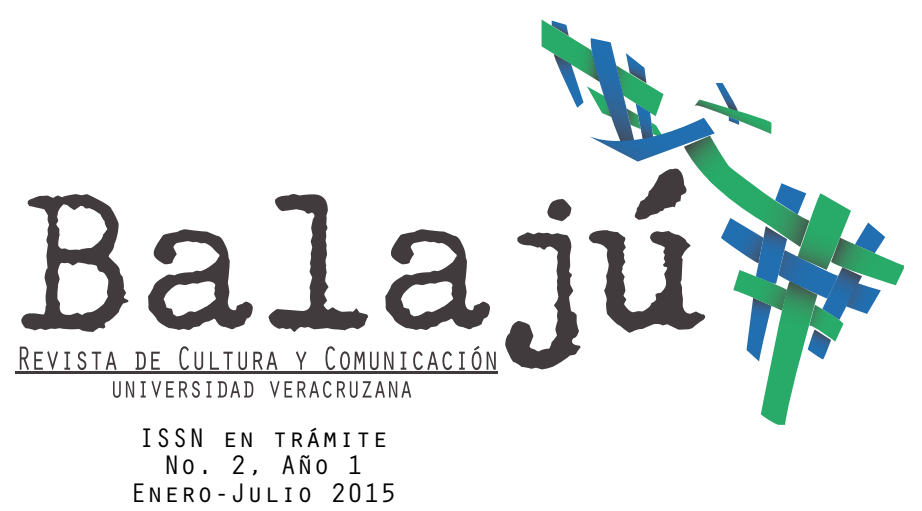

Presentación del libro Nuevos riesgos, viejos encuadres: la escenificación de la inseguridad pública en Sonora de Víctor Hugo Reyna

Guadalupe H. Mar

Universidad Veracruzana, México guadalupehmar@yahoo.com 


\section{Presentación del libro Nuevos riesgos, viejos encuadres: la escenificación de la inseguridad pública en Sonora de Víctor Hugo Reyna}

El libro que hoy presentamos consta de 228 páginas, distribuidas en cuatro capítulos, en donde se aborda el extravío normativo del periodismo y la crisis por la que atraviesa; la escenificación de la inseguridad pública, las ejecuciones y el narcotráfico, así como los viejos encuadres que aplican los medios de comunicación para los nuevos riesgos que enfrentan.

Nuevos riesgos, viejos encuadres. La escenificación de la inseguridad pública en Sonora es novedoso en la medida en que nos hace reflexionar acerca de la crisis que viven los medios de comunicación y de las soluciones, a veces tan simples, que damos a manera de diagnóstico los investigadores y periodistas, soluciones que repetimos como recetas, como esa que ofrece una salida a la crisis de los medios impresos únicamente a través del cambio de contenidos en los periódicos.

Creo que la principal aportación de este libro, su mérito y novedad, radica en señalar que la producción de contenidos diferentes no es la gran solución o la llave mágica para la crisis que viven los medios de comunicación impresos, tal y como lo demuestra esta investigación empírica, en donde está visto que una cosa es lograr un periodismo de calidad y otra es ver la calidad como panacea.

Para beneficio de aquellos que preferimos los impresos, el autor diagnostica que la crisis de los medios impresos no es sólo provocada por la falta de lectura y de lectores, la llegada de las redes sociales, la poca investigación de los perfiles de los lectores, la desconfianza de las personas hacia los medios de comunicación o el poco interés de la juventud en los sucesos de la vida contemporánea. El problema es mucho más profundo que esto y merece una perspectiva de estudio diferente en sí. Ahí radica lo interesante del libro, pues afirma el autor que es apremiante introducir un cambio de paradigma y alertar sobre el peligro de sostener esquemas del siglo pasado en el siglo XXI, porque los estudios se han quedado cortos al dar por sentado que el único inconveniente es la falta de condiciones para cumplir la función de "perro guardián" que le corresponde o le asignan a los medios de comunicación inmersos en un modelo de democracia liberal.

Sobre esta reflexión, debe mencionarse que, siguiendo ese modelo diseñado desde la democracia liberal para el periodismo, los dedicados a la investigación, a la elaboración de textos, los profesores y los perio- 
distas hemos orientado la práctica y la norma sobre todo a revitalizar la tarea de fiscalización y el monitoreo de los grupos de poder, sin reparar en planteamientos normativos alternativos y sin contemplar los alcances y limitaciones del tipo de periodismo que defendemos.

En este libro, el investigador Víctor Hugo Reyna rechaza que el único problema dentro del periodismo sea que no hay condiciones para ejercer el periodismo a manera de watchdog. Hasta ahora los estudios sobre la crisis del periodismo, a decir del autor, han privilegiado nociones de crisis acotadas a la recesión económica y a la pérdida de influencia societal de la industria periodística y no se ha observado que también consiste en la incapacidad de institución que han manifestado los modelos alternativos de periodismo. Es decir, han equiparado la crisis del periodismo con el colapso de la vieja industria periodística, sin percibir las contradicciones internas del nuevo periodismo, sea éste etiquetado como ciudadano, digital, poscorporativo y/o posindustrial, como la otra parte del proceso de degradación e incertidumbre generalizada. Para el autor, el periodismo es un objeto de estudio complejo, que permite y requiere abordajes desde múltiples perspectivas, y su crisis no es lineal ni dependiente de la voluntad de un jefe de Estado o de un actor político.

Nuevos riesgos, viejos encuadres... es un estudio del periodismo en medio de la crisis de seguridad que vive el país. El estudio inició con el parteaguas que significó en el estado de Sonora la desaparición del periodista del diario El Imparcial, Alfredo Jiménez, quien fue clave en la historia del periodismo sonorense; a este respecto el autor nos orienta en cuanto a la comprensión de esta crisis.

Víctor Hugo Reyna analiza el riesgo en la sociedad contemporánea y lo novedoso, entre otras cosas, es que atiende los niveles meso y micro de las normas y las prácticas periodísticas. Para el autor, el estudio del periodismo debe hacer espacio para discutir y desarrollar maneras alternativas de realizar esta práctica y de contribuir a la vida pública.

El autor construyó para la investigación empírica un marco teórico a partir de la teoría de la sociedad del riesgo de Ulrich Beck, estableciendo como técnica la escenificación del riesgo. Por ello, el estudio del periodismo en Sonora se enmarca en un momento de crisis -la desaparición del periodista Alfredo Jiménez-, y desde ahí estudia la reacción de los medios ante este ataque al periodista, que es vista por el resto de sus compañeros como una afectación al ambiente, que impide que los medios de comunicación puedan conducirse como perros guardianes de la ciudadanía, atacada ahora no sólo por el poder político sino también por los grupos delictivos. Y en lugar de que periodistas y medios de comunicación aprovechen la coyuntura para hacer un ejercicio mínimo de 
autocrítica y reevalúen sus fundamentos normativos, el autor nos hace ver que el periodismo mexicano se encierra en sí mismo.

Para insistir en la importancia de este texto que muestra otra perspectiva en el tema de violencia y medios de comunicación, perspectiva no explotada hasta el momento, el autor hizo investigación acerca de los titulares de la primera plana en los diarios El Imparcial y Expreso del estado de Sonora, los cuales estudió en un periodo que comprendió cuatro años, divididos en dos periodos, el primero de 2005 al 2006 y el segundo de 2009 a 2010.

Utilizando, entre otras técnicas, el análisis del discurso y el análisis de contenido, estableció categorías para el estudio como el número de fuentes, tipo de fuentes, de qué tipo de inseguridad pública trataban los titulares de los diarios estudiados, para luego cuantificarlo y arrojar datos acerca de cómo caracterizaban a las víctimas. A manera de complemento levantó encuestas a periodistas, experiodistas y alumnos de periodismo, para registrar sus percepciones sobre los ideales del periodismo, la objetividad y la función de investigar. Hizo entrevistas a profundidad a los profesionales del periodismo y analizó 3973 informaciones y titulares; 2358 del diario El Imparcial y 1615 de Expreso. Resultado de todo ello es este estudio de caso comprensivo que aborda el punto de intersección entre la crisis del periodismo y la crisis de seguridad, con lo que llega a demostrar que esta especie de autocensura y de baja mediática de los hechos violentos provocados por los grupos delictivos no se debe a las acciones punitivas en contra de reporteros y editores, sino a la crisis que viven los medios impresos de comunicación.

Definitivamente estamos ante una obra que mueve paradigmas y nos lleva a la reflexión, sobre todo a los docentes, que seguimos anidando en las mentes de los futuros periodistas los ideales de fiscalización y monitoreo, caracterizándolos de manera romántica y hasta ingenua -según advierte este libro, que nos movió el piso-, en imágenes de Manuel Buendía y Jesús Blancornelas.

Si dividiéramos el libro en lo más importante y lo menos importante de sus contenidos, resaltaría como lo primero el movernos hacia la reflexión del papel de guía del profesor del área de periodismo, en donde seguimos enseñando con bastante ausencia de malicia el periodismo de investigación, sin siquiera mover al análisis, a la reflexión de cómo fue posible que dos periodistas norteamericanos pusieran contra la espada y la pared al presidente de su país, si no es con las acciones del juez que llevó el caso, movido también por intereses personales. Y qué decir de los académicos, quienes también nos vemos reflejados en este interesante libro, destacable por la novedosa perspectiva en el abordaje de la violencia 
y los medios de comunicación. Aquí los académicos exigimos al Estado la irrestricta libertad de expresión, sin problematizar acerca de la economía política de la escenificación de la inseguridad pública.

Sería muy interesante un diálogo que involucre a académicos, profesores y ciudadanía, en donde se pudiera analizar no sólo al periodismo de investigación, que es un contenido especializado, sino la simple tarea del periodismo en Veracruz, Sonora y el país en general.

En Veracruz se hacen esfuerzos por comprender la violencia que azota al país y la reacción de los medios de comunicación y periodistas. Estos estudios que se hacen en territorio veracruzano pueden complementarse con esta investigación que hoy presentamos aquí. 